\title{
Implementation Of Pancasila Value During Covid-19 Pandemic: Case Study From Musi, Rawas District, Indonesia
}

\author{
Juliana Tirza \\ Social Studies Education, Pelita Harapan University \\ Email: mj.tirza@gmail.com
}

\begin{abstract}
A case that draws researcher attention to criticism is the deduction of direct cash assistance funds in the Musi Rawas area, South Sumatra. In the era of the Covid-19 pandemic, Indonesia is hit by an economic crisis that touches all society levels. The economic crisis can be seen from many businesses that went bankrupt, and workers who were laid off or laid off. Therefore, the government provides social support for middle to lowerincome communities affected by the crisis, ranging from foodstuffs to cash assistance. However, it turns out that all of this is not easy to get into the community's hands as a whole. Until now, Indonesia is still trying to get away from the problem of corruption. Corruption in Indonesia occurs from the government to the general public. In Indonesia, corruption has become commonplace and underestimated by the public because of the lack of a sense of unity within the community and more concerned with individual interests that impact people and other layers of society. The efforts taken to eradicate corruption have not shown any signs of success. Therefore, we would like to examine the following matters, which are why is corruption considered to violate the values of Pancasila? And how is the implementation of Pancasila values in the corruption case at Musi Rawas? The method used was qualitative with observation as the tools of data collection. This case study found that that corruption occurred because they didn't implement Pancasila values in everyday life. Therefore we can increase understanding of Pancasila values and educate others to overcome the moral crisis in Indonesia. In this challenging time, all society levels are affected, but that does not mean that all means can be justified for personal gain.
\end{abstract}

Keywords

Implementation of Pancasila, Corruption, Covid-19

Article Received: 10 August 2020, Revised: 25 October 2020, Accepted: 18 November 2020

\section{Introduction}

In the era of the Covid-19 pandemic, Indonesia is hit by an economic crisis that touches all society levels. The economic crisis can be seen from many businesses that went bankrupt, and workers who were laid off or laid off. Therefore, the government provides social support for middle to lower-income communities affected by the crisis, ranging from foodstuffs to cash assistance. However, it turns out that all of this is not easy to get into the community's hands as a whole. The people who should have received assistance have lost part of their rights because many people take advantage of the situation to perform fraud that is detrimental to society. This can be seen from the increasing number of cases in this pandemic era, one of which is corruption, which we will address.

At present, the younger generation has become immune to the terms and phenomena of corruption so that corruption is recognized as a natural thing to happen. Disgraceful actions in corruption, such as lying, cheating, extortion, etc. can become a habit that the younger generation imitated. Of course, disgraceful actions are very worrying because, in the hands of the younger generation, the nation's continuity and welfare are trusted. Supposedly, the younger generation as the nation's successor must have a sensitive attitude towards society's problems, especially those related to the surrounding environment.

Pancasila is formed as a foundation for the nation and state for all Indonesian citizens. Pancasila's values should be a value that is implemented so that a safe and peaceful life can be realized. The low level of understanding of Pancasila also makes many moral deviations that occur in Indonesia.
Therefore, it requires a deep understanding of the values of Pancasila each. Indonesian national color.

A case that draws our attention to criticism is the deduction of direct cash assistance funds in the Musi Rawas area, South Sumatra, where two village officials took illegal fees for direct cash assistance to village funds. The two perpetrators were arrested by the Musi Rawas Police Pungli Saber Team at the Banpres Village Hall when direct cash assistance originating from village funds was distributed on Sunday, May 31, 2020.

The reason researcher chose this case is that I think this case is very concerning. Community rights to receive assistance have been abused. It is unfortunate when many people only care about their interests in this challenging situation. We are as Indonesian citizens who are guided by Pancasila, should apply Pancasila values, one of which is caring for others. In our opinion, there are still many people who put aside common interests and only prioritize their respective egos, especially the corruptors who only want to enrich themselves by exercising others' rights. The state's interests and welfare should be the main focus in the life of the nation and state.

Until now, Indonesia is still trying to get away from the problem of corruption. Corruption in Indonesia occurs from the government to the general public. In Indonesia, corruption has become commonplace and underestimated by the public because of the lack of a sense of unity within the community and more concerned with individual interests that impact people and other layers of society. The efforts taken to eradicate corruption have not shown any signs of success. Therefore, we would like to examine the following matters, which are why is corruption considered to violate 
the values of Pancasila? And how is the implementation of Pancasila values in the corruption case at Musi Rawas?

\section{Theory}

There are various kinds of definitions of corruption put forward by various figures. According to Klitgaard, corruption is behavior that deviates from the official duties of a state office because of personal status or monetary benefits (individual, close family, own group) or violates the rules for implementing some personal behavior (Handoyo, 2009). Meanwhile, according to Baharudin Lopa, corruption is a criminal act of bribery and illegal acts that are detrimental or detrimental to state finances or the country's economy, detrimental to the welfare or interests of the people (Nugrahaningsih \& Utami, 2014-2015). From the explanation of the two figures, it can be concluded that corruption is a deviant action against the law and is carried out to benefit an individual or a specific group of society.

In-Law no. 31 of 1999 jo. Law No.20 of 2001 concerning the Eradication of Corruption Crime, which is spelled out in 13 articles, corruption is grouped into seven groups, namely: corruption related to detrimental to state finances, corruption related to bribery, corruption related to embezzlement in office, corruption related to extortion, corruption related to fraudulent acts, corruption related to conflicts of interest in procurement, corruption related to gratification (Syahroni, Maharso, \& Sujarwadi, 2018).

The cause of so much corruption in Indonesia is the emergence of a public mindset that if someone gets wealth, that person can be successful. Therefore, people will do anything to get this wealth, including corruption, that is detrimental to society and the country. Weak religious, moral, and ethical education is another cause that causes people to commit corruption.

In the current pandemic era, the Indonesian people's economic condition has become unstable because most of the community's sources of income are blocked or even stopped. This external factor is one of the triggers for an individual to commit corruption to get large amounts of money instantly to meet their basic needs.

Many factors cause corruption, either from within the perpetrator or from outside the perpetrator. As Yamamah said that when society's materialistic and consumptive behavior and the political system are still "deifying" the material, it can "force" the occurrence of money games and corruption. "With this condition, it is almost certain that all officials will then" resort to "corruption when they are in office." Nur Syam (2000) provides the view that a person commits corruption due to his temptation to the material world of wealth that he cannot withstand. When the urge to be rich cannot be resisted while access to wealth can be obtained through corrupt means, someone will commit corruption. Thus, if we use the point of view of corruption's cases like this, then one of the causes of corruption is the perspective on wealth. The wrong perspective on wealth will lead to the wrong way to access wealth (Puspito, S., Utari, \& Kurniadi, 2011, p. 39).

\section{Method}

Qualitative research is used to understand how people experience the world. While there are many approaches to qualitative research, they tend to be flexible and focus on retaining rich meaning when interpreting data.

This research used Phenomenological research, Researchers investigate a phenomenon or event by describing and interpreting participants' lived experiences. Researcher made an observation toward phenomenon that happened in the society. The observation was focused in Musi, Rawas area. Research looking for the root of this situation, and why the corruption during this pandemic violated the Pancasila's value and how about the implementation of Pancasila there during this pandemic. Researcher used observation as data collection methods and also secondary research from some researches that made before related to this topic.

\section{Discussion}

The case that we highlighted is a cut in village assistance funds in the Musi Rawas area, South Sumatra, where two village officials took illegal direct payments for village funds. The two perpetrators were arrested by the Musi Rawas Police Pungli Saber Team at the Banpres Village Hall when direct cash assistance originating from village funds was distributed on May 31, 2020. The police managed to collect money worth 3.6 million rupiahs from 18 families' deduction as evidence. The authorities in charge have followed up on this case, and the two corruptors have been named suspects and are threatened with a sentence of 4 to 12 years in prison and subject to the Corruption Law.

From the problems that we highlighted, we got an understanding that this case was included in a criminal case of corruption because it contained an act of embezzlement of money that resulted in harm or harm to specific groups of society, and the two individuals had violated existing laws, to be precise Law No. 20 of 2001 Article 12, Article 423 of the Criminal Code, and Article 8 of the Corruption Law. Besides, this case can also be included in corruption because illegal fees are a form of gratification (Maria Silvya E. Wangga, 2019).

The legal basis contained in the corruption case that we examine is Article 423 of the Criminal Code, where an official to benefit himself or another person is against the law, by abusing his power, forcing someone to give something, to pay or receive a discounted payment, or to do something for himself, is punishable by a maximum imprisonment of six years (Svinarki, 2016). Then, there is also Article 12e - Law No. 20 of 2001 is punished with life imprisonment or imprisonment for a minimum of 4 (four) years and a maximum of 20 (twenty) years and a fine of at least IDR 200,000,000.00 (two hundred million rupiahs) and a maximum of Rp1,000,000,000.00 (one billion rupiahs). Civil servants or state officials who intend to benefit themselves or others unlawfully, or by abusing their power force someone to give something, pay, or receive a cut payment, or do something for themselves (KPK, 2006).

In this case, the values of Pancasila were not implemented by the two corruptors. If it is related to the first principle, all religions would want if their people care about others, all 
religions teach their followers to love and respect others. When viewed for the second principle, it can be concluded that acts of corruption do not symbolize justice or humanity because they violate human rights and constitute an act of fraud. Suppose it is related to the third principle, which relates to the values of nationalism and unity. In that case, it can be seen that corruption is an act of selfishness because it prioritizes personal or particular group interests over the interests of the community or national, resulting in hampered national or regional development. If it is linked to the fourth principle regarding deliberation and consensus, community representatives are given the people's trust to manage their respective countries or regions according to their authority, but that trust is damaged by enriching themselves. When linked with the fifth principle, acts of corruption indicate a widening social gap, the poor are increasingly left behind from an economic perspective. Therefore, in carrying out acts of corruption, a person does not uphold Pancasila's value in his daily life and therefore violates the five principles of Pancasila.

The phenomenon of cases like this can occur due to a lack of understanding and experience of the Indonesian people regarding Pancasila. In carrying out corrupt actions, the community must also be aware and understand that this is an act that is not praiseworthy where there are other people's rights that should not be owned or taken. Besides, in Pancasila, it can also be seen that Indonesia is the rule of law (article 1 paragraph 3 of the 1945 Constitution) in which each of the people must do what is right and not commit any violations of the law (Saputra, 2017).

\section{Conclusion}

From this problem, researcher concludes that corruption occur because they don't implement Pancasila values in everyday life. Therefore we can increase understanding of Pancasila values and educate others to overcome the moral crisis in Indonesia. In this challenging time, all society levels are affected, but that does not mean that all means can be justified for personal gain. Clearly, in this matter, there has not been any public awareness to apply the values of Pancasila in social and state life.

Researcher concludes that two solutions can be done to prevent corruption cases, namely by building a culture of anti-corruption in society to build attitudes and morals. Anticorruption education has been well educated since we were in the family environment, and continues to be taught in schools and continues to be applied in life. Social media is also one of the suitable means to instill Pancasila education in everyday life because the target we have achieved is to reduce the number of corruption cases for Indonesia's future, which is the current young generation. All young people are now very active in using the media. Social. We can also carry out anti-corruption campaigns carried out in various media, especially the mass media. Prevention can also be done through consistent and integrated law enforcement that brings benefits to society, namely causing a deterrent effect to prevent someone from committing corruption.

\section{References}

[1] Handoyo, D. E. (2009). Pendidikan Anti Korupsi. Semarang: Penerbit Ombak. Retrieved from http://lp3.unnes.ac.id/v2/wpcontent/uploads/2019/03/Pendidikan-AntiKorupsi-Suplemen-MKU-Pend.Konservasi.pdf

[2] KPK. (2006). Memahami Untuk Membasmi. Jakarta: Komisi Pemberantasan Korupsi. Retrieved from https://www.kpk.go.id/gratifikasi/BP/buku _saku_korupsi.pdf

[3] Maria Silvya E. Wangga, R. B. (2019, April). PENEGAKAN HUKUM KORUPSI POLITIK. Kanun Jurnal Ilmu Hukum, 21, 49. doi:https://doi.org/10.24815/kanun.v21i1.1 2862

[4] Nugrahaningsih, W., \& Utami, I. W. (2014 - 2015). PANCASILA SEBAGAI SUMBER HUKUM BAGI ANTI KORUPSI DAN MENJUNGJUNG HAK ASASI MANUSIA. Jurnal Serambi Hukum , 8, 193.

[5] Puspito, N. T., S., M. E., Utari, I. S., \& Kurniadi, Y. (Eds.). (2011). Pendidikan Anti Korupsi Untuk Perguruan Tinggi. Jakarta: Kementerian Pendidikan dan Kebudayaan RI .

[6] Saputra, I. (2017, Juni). IMPLEMENTASI NILAI PANCASILA. JPPKn, 2, 13. Retrieved file:///C:/Users/ACER/Downloads/83Article\%20Text-154-1-1020170621(1).pdf

[7] Svinarki, I. (2016). PEMBERANTASAN TINDAK PIDANA KORUPSI TERHADAP PUNGUTAN LIAR (PUNGLI). Jurnal Cahaya Keadilan, 4, 76. Retrieved from file://C:/Users/ACER/Downloads/935-853107-1-10-20190108.pdf

[8] Syahroni, Maharso, \& Sujarwadi, $\mathrm{T}$. (2018). Korupsi, Bukan Budaya tapi Penyakit. Sleman: CV BUDI UTAMA. Retrieved from 
https://books.google.co.id/books?id=z4VJ

DwAAQBAJ\&printsec $=$ frontcover $\& \mathrm{dq}=\mathrm{k}$

orupsi\&hl=en\&sa=X\&ved=2ahUKEwicu 4 v42JzsAhXLdn0KHb75CKkQ6AEwAnoE

CAUQAg\# $\mathrm{v}=$ onepage $\& \mathrm{q}=$ korupsi\& $\mathrm{f}=$ fals

e

[9] Waluyo, B. (2014, Desember). Optimalisasi Pemberantasan Korupsi di Indonesia. Jurnal Yuridis, 1, 175 - 179. Retrieved from https://media.neliti.com/media/publication s/282159-optimalisasi-pemberantasankorupsi-di-in-6faf3218.pdf

[10] AM, M. (2020, June 03). Korupsi Bantuan Corona Rp 200 Ribu Per KK, Polisi Ciduk 2 Pelaku dan Barang Bukti Jutaan Rupiah. Retrieved September 28, 2020, from https://makassar.tribunnews.com/2020/06/ 03/korupsi-bantuan-corona-rp-200-ribuper-kk-polisi-ciduk-2-pelaku-dan-barangbukti-jutaan-rupiah

[11] Gusti, M. (2020, June 3). Korupsi Dana Bantuan, Pelaku Memotong Rp 200.000 dari Setiap Keluarga. Retrieved September 28, 2020, from https://www.google.com/amp/s/www.kom pas.tv/amp/article/84622/videos/korupsidana-bantuan-pelaku-memotong-rp-200000-dari-setiap-keluarga

[12] Triono, E. (2020, June 02). Polisi Ciduk Oknum Kadus dan Anggota BPD di Sumsel yang Berani Potong Dana BLT DD Covid-19. Retrieved September 28, 2020, from https://www.viralsumsel.com/polisi-cidukoknum-kadus-dan-anggota-bpd-di-sumselyang-berani-potong-dana-blt-dd-covid-19/ 